\title{
Medication Review for Hospitalized Pediatric Patient: Clinical Pharmacist Interventions
}

\author{
Hastanede Yatan Pediatrik Hastalarda Ilaç Tedavisinin İncelenmesi: \\ Klinik Eczacı Önerileri
}

\author{
Merve Nur Işık'(iD), Nazan Dalgıç²(iD), Betül Okuyan'(iD), Zeynep Yıldız Yıldırmak(iD), Mesut Sancar'(iD) \\ ${ }^{1}$ Department of Clinical Pharmacy, Marmara University Faculty of Pharmacy, Istanbul, Turkey \\ ${ }^{2}$ Clinic of Pediatric Infectious Diseases, Şişli Hamidiye Etfal Training and Research Hospital, Istanbul, Turkey \\ ${ }^{3}$ Clinic of Pediatric Hematology and Oncology, Şişli Hamidiye Etfal Training and Research Hospital, İstanbul, Turkey
}

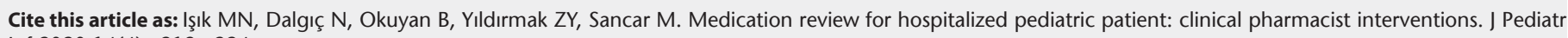
Inf 2020;14(4):e218-e224.

Abstract

Objective: The aim of this study is to evaluate clinical pharmacist-led medication review service for hospitalized pediatric patients.

Material and Methods: This cross-sectional study was carried out between November 2017-April 2018 in an education and research hospital in Istanbul. Clinical pharmacist-led medication review was conducted by using Pharmaceutical Care Network Europe (PCNE) Classification V8.02 in hospitalized pediatric at general pediatric service. Potential drug-related problems (DRPs) were identified and classified. These DRPs were presented the physicians and the percentage of accepted recommendations by the physician were recorded.

Results: Among forty-three patients (21 male and 22 female), the median age of them was calculated as 6 (3-36) months. Of them, $25.58 \%$ had 16 DRPs. The most common DRPs were associated with potential drug-drug interactions $(n=9)$; and dose selection $(n=5)$, which represented $56.25 \%$ and $31.25 \%$ of drug-related problems, respectively. It was observed that $63 \%$ of these problems were occurred during selection of drugs (at prescription level) according to PCNE classification. Of the clinical pharmacist's recommendations regarding these DRPs, $87.5 \%$ were accepted by the physician.

Conclusion: To optimize rational drug use, numerous studies related with clinical pharmacist-led medication review by using PCNE classification were present in adult patients; however, there was no sufficient studies conducted in pediatric patients. Clinical pharmacists have an important role in the classification of DRPs and to provide rational drug use in pediatric patients.

Keywords: Pediatrics, medication review, drug related problem, clinical pharmacist
Öz

Giriş: Bu çalışmada, hastanede yatan pediatrik hastalar için klinik eczacı tarafından yürütülen ilaç incelemesi hizmetinin değerlendirilmesi amaçlanmıştır.

Gereç ve Yöntemler: Bu kesitsel çalışma Kasım 2017-Nisan 2018 tarihleri arasında İstanbul'da bir eğitim ve araştırma hastanesinde gerçekleştirilmiştir. Farmasötik Bakım Avrupa Ağı (Pharmaceutical Care Network Europe [PCNE]) V8.02 sınıflandırması kullanılarak klinik eczacı tarafından yürütülen ilaç incelemesi, genel pediatri servisinde yatan hastalarda yürütülmüştür. Olası ilaçla ilişkili sorunlar saptanmış ve sınıflandırılmıştır. $\mathrm{Bu}$ olası sorunlar, hekime sunulmuş ve hekim tarafından kabul edilen önerilerin oranları kaydedilmiştir.

Bulgular: Çalışmaya 22'si kız, 21'i erkek olmak üzere 43 hasta dahil edilmiştir ve bu hastaların ortanca yaşı 6 (3-36) ay olarak hesaplanmıştır. Hastaların \%25.58'inde 16 ilaçla ilişkili sorun saptanmıştır. En sık gözlenen ilaçla ilişkili sorunlar, olası ilaç-ilaç etkileşimi $(n=9)$ ve doz seçimi $(n=5)$ olup, bunlar ilaçla ilişkili sorunların sırasıyla \%56.25 ve \%31.25'ini oluşturmaktaydı. PCNE sınıflandırmasına göre, bu sorunların \%63'ünün ilaç seçimi sırasında (reçeteleme düzeyinde) oluştuğu görülmüştür. Bu olası ilaçla ilişkili sorunlara yönelik klinik eczacı önerilerinin \%87.5'i hekim tarafından kabul edilmiştir.

Sonuç: Erişkin hastalarda rasyonel ilaç kullanımını sağlamak için PCNE sınıflandırılması kullanılarak klinik eczacı tarafından yürütülen ilaç incelemesi ile ilgili pek çok çalışma mevcuttur; ancak pediatrik hastalarda yeterli çalışma bulunmamaktadır. Klinik eczacılar, pediatrik hastalarda ilaçla ilişkili sorunların saptanması ve akılcı ilaç kullanımının sağlanmasında önemli bir role sahiptir.

Anahtar Kelimeler: Pediatri, ilaç incelemesi, ilaçla ilişkili sorun, klinik eczacl

\author{
Correspondence Address/Yazışma Adresi \\ Mesut Sancar \\ Marmara Üniversitesi, Eczacılık Fakültesi, \\ Klinik Eczacılık Anabilim Dalı, \\ Istanbul-Türkiye \\ E-mail:mesut.sancar@marmara.edu.tr
}

Received: 23.04 .2020

Accepted: 25.06 .2020
(Copyright 2020 by Pediatric Infectious Diseases and Immunization Society. Available online at www.cocukenfeksiyon.org 


\section{Introduction}

Although medications are vital in the treatment of diseases, they may occasionally cause drug-related problems in patients. Since the pediatric population has a pharmacodynamically and pharmakinetically different nature compared to adults, these patients are faced with more problems (1). Moreover, studies investigating drug-related problems in children are insufficient, and the sources are limited (2). According to the definition given by the Pharmaceutical Care Network Europe (PCNE), drug-related problem is an event or condition regarding the treatment process that prevents or has the potential to prevent the desired health outcome (3). Medication review is defined as the medication evaluation carried out to make fit drug use and improve health outcomes of the patients (4).

Medication errors are the cause of significant risks and damage $(5,6)$. These errors can be seen in the process of drug prescriptions, administration, distribution and monitorization (7). According to a research, due to illegible prescriptions and not providing instant feedback on the computer system in the event of drug interactions, overdose or misuse of the drug, the incidence rate of errors is much higher. Various computer programs have been developed to this end, but medication errors could not be fully prevented $(8,9)$. In studies investigating the effect of the clinical pharmacist taking part in the treatment process, it has been reported that lack of knowledge and insufficient monitoring are the most common causes of drug-related problems $(10,11)$.

Drug-related problems lead to emergency service and hospital presentations, additional prescriptions, hospitalization and also give rise to significant financial costs (2). For instance, the economic load arising from drug-related morbidity and mortality in outpatients in the USA in 2000 was calculated as 177.4 billion dollars (12). Therefore, drug-related problems do not only affect the patient but also the society $(13,14)$. In a study in which pharmacists have evaluated and intervened in drug-related problems, it has been observed that these interventions prevent adverse drug reactions and decrease treatment cost $(15,16)$.

American Pediatric Academy has made several recommendations on how to decrease drug-related problems. These recommendations include the usage of computer systems, standard dose and calculation methods, and preparing and controlling the drugs in the pharmacy. Furthermore, employing a clinical pharmacist in the pediatric service is also one of the recommendations (17). Again, the American Pediatric Academy emphasizes that an actively participant multidisciplinary team comprising of a physician, nurse, pharmacist, laboratory staff and IT specialists would significantly decrease medication errors in children. This report prepared in 2003 mentioned the necessity of clinical pharmacists visits, togeth- er with the physician and nurse, especially in the intensive care and oncology services would be helpful in decreasing to the minimum the medication errors in the pediatrics department of hospitals and also included the responsibilities of the pharmacists that would be employed in these services (18).

It is seen that in various countries worldwide, the incidence of drug-related problems in the general pediatric services varies between $18.7 \%-52.6 \%(2,19)$. In a multi-center study carried out in Malaysia, at least one error has been encountered in $9.2 \%$ of the prescriptions, $1.8 \%$ of which have been serious or fatal (20). Most commonly seen drug-related problems in pediatric patients include dosing problems, wrong drug selection, and adverse drug reactions $(2,21,22)$. The studies carried out have concluded that the majority of these problems are preventable $(20,22,23)$.

A systematic review and reporting system are needed in order to detect drug-related problems. To this end, a scheme was formed aimed at the classification of these problems at a working conference of the Pharmaceutical Care Network Europe (PCNE) in 1999. This classification was designed with the intention of researching the prevalence and incidence of drug-related problems and documenting possible problems in medicinal treatment, and helping healthcare workers (3).

In the literature, there are various studies carried out to detect drug-related problems in pediatric patients and determine the role of the clinical pharmacist in finding and intervening in these problems $(24,25)$; however, to the best of our knowledge, there are not many studies conducted in this field in our country. This study aimed at evaluating the medication review service provided by the clinical pharmacist in order to detect potential drug-related problems in pediatric patients.

\section{Materials and Methods}

This study carried out as a Master's thesis in an education and research hospital in Istanbul between November 2017 and April 2018 included the inpatients of the general pediatric service. Patients admitted to the Pediatric Hematology and Pediatric Intensive Care Unit ( $<18$ years) were not included into the study. Approval no.1705 from the ethics board of the hospital where the study was conducted had been received in 10.03.2017. Data collection was carried out one day of the week by the clinical pharmacist and within the knowledge of relevant physician. Even if data had to be collected again on separate days for one patient, this situation was again accepted as a single review. Due to the long hospital stays of the patients (7-10 days), a limited number of patients (43 patients) could be included into the study.

A "patient tracking form" to collect information on the patients was prepared, and through this form, the demographic and clinical information of the patients (age, sex, weight, previous disease history, present diseases and the drugs used, 
Işık et al.

presentation complaints, diagnosis, hospital treatment and prescribed drugs) were retrieved from physicians' and nurses' charts. Intravenous fluids were excluded from the study.

The patient file was evaluated by the researcher (graduate student of clinical pharmacy) according to the PCNE V8.02 classification, and drug-related problems were classified (3). PCNE is a tool consisting three basic areas for problems, 8 basic areas for causes and 5 areas for interventions. Nevertheless, there are also subareas group in a more detailed level including 7 subareas for problems, 35 subareas for causes, and 16 subareas for interventions. These subareas are accepted explanatory for the primary areas. An average of 15 minutes was devoted to the PCNE evaluation of one patient file. Errors originating from drug preparation and use could not be reviewed due to limitations in human power and time. No interviews with the patients took place during this study, and therefore no intervention was made or report submitted at patient level.

Interaction setween the prescribed drugs were checked by the Lexicomp ${ }^{\oplus}$ database. Drug-drug interactions in category $X$ (avoid combination) and $\mathrm{D}$ (recommend change in treatment plan) were accepted as drug-related problems. C category (monitor closely) interactions were not included into the study since the patients were followed as inpatients in the hospital.

Potential drug-related problems were detected by the clinical pharmacist within the first week of the patients' discharge, and all possible problems were reviewed together with a specialist clinical pharmacist. Potential problems reached with mutual conclusion were submitted to the physicians at the end of the study, and feedback in the form of acceptance and rejection was received.

Continuous variables were given as median and ordinal and normal values were presented as $n(\%)$ in the study. SPSS 11.0 package program was used for data analysis.

\section{Results}

Drug data of a total of 43 patients, 21 males and 22 females, admitted in the inpatient clinic of the general pediatrics service were evaluated according to PCNE. Median age of the patients included into the study was found as 6 (3-36) months.

When patient data was evaluated, it was seen that 8 patients received more than one diagnosis and the patients were most frequently admitted due to lower respiratory tract infections such as bronchiolitis and bronchopneumonia (Table 1). Therefore, medication classes most frequently prescribed were drugs of the respiratory system (29.37\%) and anti-infective agents (24.37\%). Patient drug data were evaluated according to PCNE and drug-related problems were classified in Table 2. A total of 16 potential drug-related problems were detected in 11 of the 43 patients included into the study. It was seen in this case that at least one potential drug-related problem was present in $25.58 \%$ of the patients. The most commonly observed problems were potential drug-drug interaction $(n=9)$ and dosage selection $(n=5)$, which constituted $56.25 \%$ and $31.25 \%$ of the problems, respectively. Apart from $1 \mathrm{X}$ and $8 \mathrm{D}$ category drug interactions that required warning, a total of 38 $C$ category (monitor treatment) drug interactions were seen in 15 of the 43 patients (Figure 1). However, $C$ category interactions were not included into the recommendations made to the physician since inpatients were already under observation and the clinical significance of these interactions did not indicate treatment change. Potential drug-drug interactions and their prevalence are summarized in Table 3.

As shown on Figure 2,63\% of the potential drug-related problems were observed at the drug selection process, $31 \%$ at the dose selection process, and $6 \%$ at the drug use process. Dose-related problems were seen in the dosages of cefotaxime, vancomycin and clarithromycin. It was observed that the doses of cefotaxime and vancomycin were lower for the indication determined and that of clarithromycin was higher. Problems related to antibiotic dosage were not observed in 3

Table 1. Diagnostic information of the patients

\begin{tabular}{|l|c|}
\hline Indication & Number of Indications \\
\hline Acute bronchiolitis & 17 \\
\hline Bronchopneumonia & 5 \\
\hline Gastroenteritis & 4 \\
\hline Epilepsy & 2 \\
\hline URTI & 2 \\
\hline Meningitis & 9 \\
\hline Other* & 9 \\
\hline $\begin{array}{l}\text { *Fever, urinary system infection, rectal hemorrhage, nephrotic syndrome, cough, } \\
\text { hydrocephaly, colitis, hypernatremic dehydration, metabolic disease. }\end{array}$ \\
\hline
\end{tabular}

Table 2. Classification of drug-related problems and their evaluation by physicians

\begin{tabular}{|l|c|c|c|}
\hline Code V8.01 & Problem & Prevalence & Accepted \\
\hline C1.3 & No indication for the drug & 1 & 0 \\
\hline C1.4 & There is an inappropriate combination of the drug with herbal products and other drugs & 9 & 9 \\
\hline C3.1 & Drug dose is too low & 3 & 3 \\
\hline C3.2 & Drug dose is too high & 2 & 2 \\
\hline C6.6 & The drug is administered through a wrong route of application & 1 & 0 \\
\hline
\end{tabular}




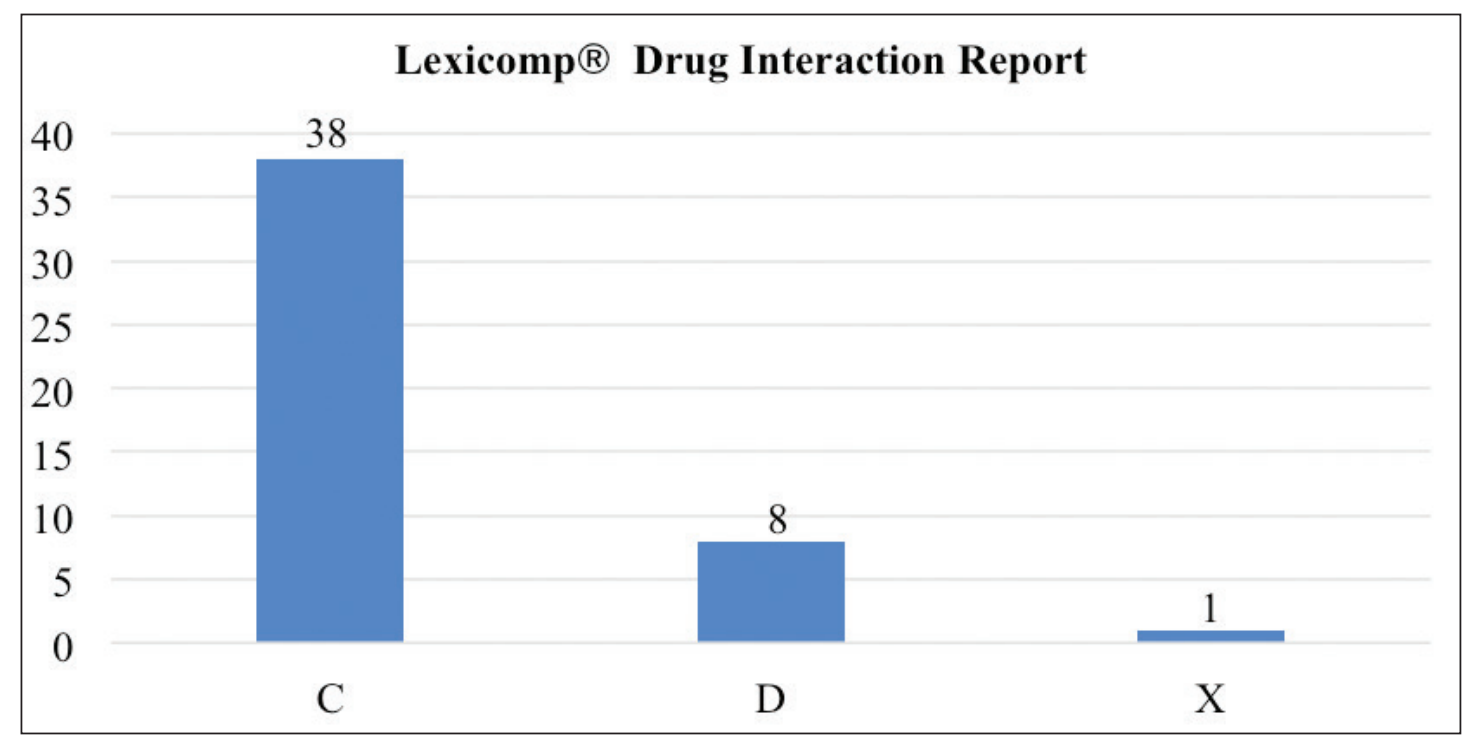

Figure 1. Drug interaction data obtained using Lexicomp ${ }^{\circledR}$ database $(n=30)$.

Table 3. Drug-drug interactions

\begin{tabular}{|l|c|}
\hline Interaction category & Prevalence \\
\hline D (Recommend change in treatment plan) & \\
Clarithromycin - Methylprednisolone & 3 \\
Clarithromycin - Dexamethasone & 1 \\
Clarithromycin - Fluticasone & 1 \\
Salbutamol - Domperidone & 1 \\
Midazolam - Phenobarbital & 1 \\
Midazolam - Phenytoin & \\
\hline X (Avoid combination) & 1 \\
Clarithromycin- Domperidone & \\
\hline
\end{tabular}

(6.97\%) of the patients. $18.75 \%$ of drug-related problems were found to be associated with antibiotic doses. Drug-related problems were seen mostly in bronchiolitis patients (50.0\%, 8 patients) and pneumonia patients (31.25\%, 5 patients).

Possible problems established by the PCNE classification were submitted to the physicians involved as reports and feedback was received. $87.5 \%$ of the possible problems given in detail on Table 2 were accepted by the physician involved.

\section{Discussion}

In this study in which medication review service carried out by the clinical pharmacist for the detection of potential drug-related problems in pediatric patients was evaluated, data of 43 patients retrieved from the inpatient clinic of the general pediatric service were reviewed according to the PCNE guideline and 16 potential drug-related problems were found in 11 patients. Sixty-three percent of the potential drug-related problems were observed at the drug selection phase, 31\% at the dose selection phase, and $6 \%$ at the drug use phase. Eighty-seven point five percent of the possible problems detected were accepted by the physicians.

The effect of clinical pharmacists on the care process and outcomes of the patients has been investigated in a system-

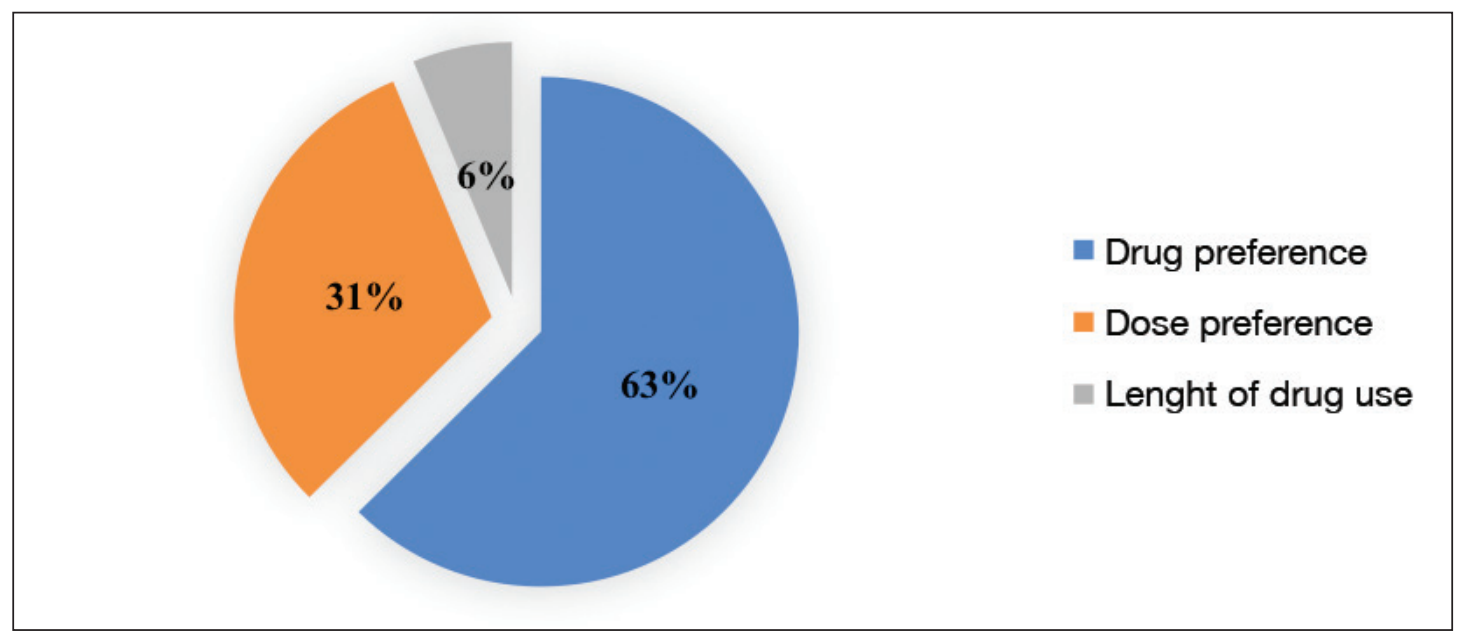

Figure 2. Percentage distribution of the stages drug-related problems are seen. 
atic review. In this review, it has been concluded that joining patient visits, clinical pharmacists prevent adverse drug reactions and decrease medication errors with the drug consensus service they have provided to specific drug groups like anticoagulants or antibiotic. Moreover, it has been observed that the patients' knowledge on the drugs is enhanced and compatibility to treatment is increased accordingly. It has also been confirmed in most of the studies that the length of hospital stays is shortened. It has been seen that involving clinical pharmacists in the multidisciplinary health teams in hospitals increases the quality, reliability and efficacy of pharmaceutical care and decreases the frequency of drug-related problems $(26,27)$.

In a study conducted in our country by a clinical pharmacist in the internal medicine clinic, data of 100 inpatients were included and a total of 163 drug-related problems were detected. At least one possible problem was identified in $80 \%$ of the patients, and mean drug-related problem per patient was calculated as $1.61 \pm 1.17$. Possible problems were mostly related to drug selection (44.79\%), dose selection $(27.61 \%)$ and drug treatment procedures (21.47\%) (28). Even though this study was carried out in adult patients, it is probable to find studies showing that possible problems in pediatric inpatients in the literature are to no less a degree to those of the adults $(28,29)$. It is believed that the detection and timely intervention of the possible problems by the clinical pharmacist will contribute to the treatment process (30). In a thorough medication review performed by a pediatric clinical pharmacist in a major academic hospital, a total of 865 medication errors (5.2 errors per 100 prescriptions) have been determined in 678 patients admitted to the pediatric service, and preventable adverse drug events have been observed at a rate of $0.09 \%$ (31).

In a study by Rashed et al. (21) carried out in the UK and Saudi Arabia in pediatric patients aged 0-18 years in 2012, potential drug-related problems were determined in $45.2 \%$ of the patients according to PCNE classification. This rate is quite high compared to ours. While problems were mostly detected during the drug selection phase in our study, 54\% of the problems reported by Rashed et al. were dose-related and $80.3 \%$ of these were found to be preventable. In another 3-month-long observational study carried out by Rashed et al. (25), 69 (22\%) drug-related problems were detected in 55 of the 253 patients included into the study, and $78 \%$ were considered preventable. In another study carried out by Law et al. (32), drug-related problems have been classified as per PCNE guidelines. A total of 315 interventions have been recorded by the pharmacists, $54 \%$ and $28 \%$ of which have been dose and drug selection-related, respectively. Fifty-four percent of the interventions have been reported as moderate, $43 \%$ as minor and $3 \%$ as major errors, and $89 \%$ of the interventions were completely solved (26).
Inpatients, aged 0-15 years, staying in the hospital for more than 48 hours were included into a 3-month-long study carried out by Birarra et al. (2) in Ethiopia in 2014. One hundred and six drug-related problems were confirmed in 90 (31.6\%) of the 285 patients included into the study. It was determined that $42.5 \%$ of the drug-related problems were dose-related and the dose was too low in $39.4 \%$ and too high in $7.5 \%$. It was also established that $38.7 \%$ of the problems were related to drug-drug interactions and $8.5 \%$ were associated with adverse drug reactions. Moreover, it was emphasized that drug-related problems were mostly observed in pneumonia (41.1\%) and asthma (20.5\%) patients (2). In our study, potential drug-related problems were seen mostly in acute bronchiolitis (50\%) and pneumonia (31.25\%) patients. The problems in Biarra et al. (2)'s aforementioned study were associated with clarithromycin the most, and drug-drug interactions were related to phenobarbital, diazepam and hydrocortisone. In our study, it was observed that dose-related problems and drugdrug interactions were associated the most with antibiotics and clarithromycin, respectively.

In a study by Feinstein et al. (33), potential drug-drug interaction (contraindicated, major and moderate) has been detected in $37 \%$ of the patients. This rate was found as $13.9 \%$ in our study. It is a notable finding that the problems determined in our study are few in number when compared to the literature.

Two hundred and twenty-five pediatric patients have been included into another 3-month-long study carried out to determine drug-related problems in the general pediatric service, their incidence and risk factors. One hundred and seventy-eight drug-related problems have been confirmed in 119 $(52.88 \%)$ of these patients. Similar to our study, the most commonly prescribed drug groups have been found as nervous system drugs $(26.9 \%)$, respiratory system drugs $(23.9 \%)$ and systemic anti-inflammatories (23.5\%). Drug-related problems have been found to arise from salbutamol inhalation (19.7\%), paracetamol use (19.7\%), and budesonide inhalation (6.6\%). It has been observed that the main reason of these problems is misinformation in any stage of reaching the drug to the patient and inappropriate dose selection (34).

The prevention of drug-related problems does not only increase the quality of treatment but also seriously decrease healthcare costs and improve patients' life quality $(35,36)$. Since it was not within the scope of our study, pharmacoeconomical dimension of the drug-related problems and their consequences on life quality were not evaluated. In addition, a limitation to our study is the limited number of cases included due to the limited time we had. Despite these limitations, we believe that our study will contribute to the literature with regard to showing clinical pharmacists as an essential part of the healthcare team in prescribing, administering and monitoring drugs in children. 


\section{Conclusion}

There are many studies carried out using PCNE guideline or other tools to detect and prevent potential drug-related problems in adults and therefore ensure rational drug use. However, it is known that there are limited number of such studies where PCNE guideline was used for the pediatric population. This study put forth that pediatric inpatients may experience drug-related problems and especially some of these may cause serious problems. Further studies are needed to investigate and decrease the negative effects of such problems on the health of pediatric patients.

\section{Acknowledgment}

This study was carried out within the scope of a Clinical Pharmacy Master's thesis completed at the Health Sciences Institute of Marmara University.

Ethics Committe Approval: The ethical approval for this study was obtained from the Ethics Committee of T.C. Ministry of Health Public Hospitals Administration of Turkey Şişli Hamidiye Etfal Training and Research Hospital Clinical Research Ethical Committe (Decision number: 1705, Date: 03.10.2017).

Peer-review: Externally peer-reviewed.

Author Contributions: Concept - MNI, MS; Design - All of authors; Supervision - ND, BO, MS; Resource - MNI, BO, MS; Data Collection and/or Processing - MNI, ND, ZYY; Analysis and/or Interpretation MNI, ZYY, MS; Literature Search - MNI, BO, MS; Writing - MNI, BO, MS; Critical Review - ND, BO, MS.

Conflict of Interest: No conflict of interest was declared by the authors.

Financial Disclosure: The authors declared that this study has received no financial support.

\section{References}

1. Baena MI, Faus MJ, Fajardo PC, Luque FM, Sierra F, Martinez-Olmos J, et al. Medicine-related problems resulting in emergency department visits. Eur J Clin Pharmacol 2006;62:387-93. [CrossRef]

2. Birarra MK, Heye TB, Shibeshi W. Assessment of drug-related problems in pediatric ward of Zewditu Memorial Referral Hospital, Addis Ababa, Ethiopia. Int J Clin Pharm 2017;39:1039-46. [CrossRef]

3. Pharmaceytical Care Network European. Available from: https://www. pcne.org/upload/files/334_PCNE_classification_V9-0.pdf Access date: 27.09.2019. [CrossRef]

4. Griese-Mammen N, Hersberger KE, Messerli M, Leikola S, Horvat N, van Mil JF, et al. PCNE definition of medication review: reaching agreement. International journal of clinical pharmacy. 2018;40:1199-208. [CrossRef]

5. Stultz JS, Porter K, Nahata MC. Prescription order risk factors for pediatric dosing alerts. Int J Med Inf 2015;84:134-40. [CrossRef]

6. Engum SA, Breckler FD. An evaluation of medication errors-the pediatric surgical service exprerience. J Pediatr.Surg 2008;43:348-52. [CrossRef]

7. Schwartzberg D, Ivanovic S, Patel S, Burjonrappa SC. We thought we would be perfect: medication errors before and after the initiation of computerized physician order entry. J Surg Res 2015;198:108-14. [CrossRef]
8. Eslami S, de Keizer NF, Abu-Hanna A. The impact of computerized physician medication order entry in hospitalized patients-a systematic review. Int J Med Inf 2008;77:365-76. [CrossRef]

9. Arques-Armoiry E, Cabelguenne D, Stamm C, Janoly-Dumenil A, Grosset Grange I, Vantard N, et al. Most frequent drug-related events detected by pharmacists during prescription analysis in a University Hospital. Rev Med Interne 2010;3:804-11. [CrossRef]

10. Rottenkolber D, Hasford J, Stausberg J. Costs of adverse drug events in German hospitals-a microcosting study. Value in Health 2012;15:868-75. [CrossRef]

11. Amelung S, Meid AD, Nafe M, Thalheimer M, Hoppe Tichy T, Haefeli WE, et al. Association of preventable adverse drug events with inpatients' length of stay-A propensity matched cohort study. Int J Clin Pract 2017;71:e12990. [CrossRef]

12. Ernst FR, Grizzle AJ. Drug-related morbidity and mortality: updating the cost-of-illness model. J Am Pharm Assoc 2001;41:192-9. [CrossRef]

13. Classen DC, Pestotnik SL, Evans RS, Lloyd JF, Burke JP. Adverse drug events in hospitalized patients. Excess length of stay, extra costs, and attributable mortality. JAMA 1997;277:301-6. [CrossRef]

14. Bates DW, Spell N, Cullen DJ, Burdick E, Laird N, Petersen LA, et al. The costs of adverse drug events in hospitalized patients. Adverse Drug Events Prevention Study Group. JAMA 1997;277:307-11. [CrossRef]

15. Gallagher J, Byrne S, Woods N, Lynch D, McCarthy S. Cost-outcome description of clinical pharmacist interventions in a university teaching hospital. BMC Health Services Research 2014;14:177. [CrossRef]

16. Tasaka Y, Tanaka A, Yasunaga D, Asakawa T, Araki H, Tanaka M. Potential drug-related problems detected by routine pharmaceutical interventions: safety and economic contributions made by hospital pharmacists in Japan. Journal of Pharmaceutical Health Care and Sciences 2018;4:33. [CrossRef]

17. Nahata MC, Taketomo C. Pediatrics. In: Di Piro JT, Talbert RL, Yee GC, Matzke GR, Wells BG, Posey LM. (eds.) Pharmacotherapy: A Pathophysiologic Approach. $9^{\text {th }}$ ed, New York:McGraw-Hill Publishing, 2014:1-21. [CrossRef]

18. American Academy of Pediatrics, Policy Statement. Prevention of medication errors in the pediatric inpatient setting. Pediatrics 2003;112:431-6. [CrossRef]

19. Rashed AN, Wilton L, Lo CCH, Kwong BYS, Leung S, Wong ICK. Epidemiology and potential risk factors of drug-related problems in Hong Kong paediatric wards. Br J Clin Pharmacol 2014;77:873-9. [CrossRef]

20. Khoo TB, Tan JW, Ng HP, Choo CM, Abdul Shukor INC, Teh SH. Paediatric in-patient prescribing errors in Malaysia: a cross-sectional multicentre study. Int J Clin Pharm 2017;39:551-9. [CrossRef]

21. Rashed AN, Neubert A, Tomlin S, Jackman J, Alhamdan H, AlShaikh A, et al. Epidemiology and potential associated risk factors of drug-related problems in hospitalised children in the United Kingdom and Saudi Arabia. EJCP 2012;68:1657-66. [CrossRef]

22. Wong ICK, Ghaleb MA, Franklin BD, Barber N. Incidence and nature of dosing errors in paediatric medications: a systematic review. Drug Saf 2004;27:661-70. [CrossRef]

23. Easton KL, Chapman CB, Brien JE. Frequency and characteristics of hospital admissions associated with drug-related problems in paediatrics. Br J Clin Pharmacol 2004;57:611-5. [CrossRef]

24. Sanghera N, Chan PY, Khaki ZF, Planner C, Lee KK, Cranswick NE, et al. Interventions of hospital pharmacists in improving drug therapy in children: a systematic literature review. Drug Safety 2006;29:1031-47. [CrossRef]

25. Rashed AN, Neubert A, Alhamdan H, Tomlin S, Alazmi A, AlShaikh A, et al. Drug-related problems found in children attending an emergency department in Saudi Arabia and in the United Kingdom. Int J Clin Pharm 2013;35:327-31. [CrossRef] 
Işık et al.

26. Bond C, Raehl CL, Franke T. Clinical pharmacy services, hospital pharmacy staffing, and medication errors in United States hospitals. Pharmacotherapy: The Journal of Human Pharmacology and Drug Therapy 2002;22:134-47. [CrossRef]

27. Gallagher J, McCarthy S, Byrne S. Economic evaluations of clinical pharmacist interventions on hospital inpatients: a systematic review of recent literature. International Journal of Clinical Pharmacy 2014;36:1101-14. [CrossRef]

28. Abunahlah N, Elawaisi A, Velibeyoglu FM, Sancar M. Drug related problems identified by clinical pharmacist at the Internal medicine ward in Turkey. Int J Clin Pharm 2018;40:360-7. [CrossRef]

29. Kaushal R, Bates DW, Landrigan C, McKenna KJ, Clapp MD, Federico F, et al. Medication errors and adverse drug events in pediatric inpatients. JAMA. 2001;285:2114-20. [CrossRef]

30. McGrady ME, Hommel KA. medication adherence and health care utilization in pediatric chronic Illness: a systematic review. Pediatrics 2013;132:730-40. [CrossRef]

31. Wang JK, Herzog NS, Kaushal R, Park C, Mochizuki C, Weingarten SR. Prevention of pediatric medication errors by hospital pharmacists and the potential benefit of computerized physician order entry. Pediatrics 2007;119:e77-85. [CrossRef]
32. Law A, Lo A, Stephenson E. Pharmaceutical interventions from paediatric pharmacists. Arch Dis Child 2010;95:e1. [CrossRef]

33. Feinstein J, Dai D, Zhong W, Freedman J, Feudtner C. Potential drugdrug interactions in infant, child, and adolescent patients in children's hospitals. Pediatrics 2014;135:99-108. [CrossRef]

34. Hon MY, Chua XY, Premakumar CM, Mohamed Shah N. Drug-related problems in a general paediatric ward of a tertiary care hospital in Malaysia. Int J Clin Pharm 2020;42:948-55. [CrossRef]

35. Lagnaoui R, Moore N, Fach J, Longy-Boursier M, Begaud B. Adverse drug reactions in a department of systemic diseases oriented internal medicine: prevalence, incidence, direct costs and avoidability. Eur J Clin Pharmacol 2000;56:181-6. [CrossRef]

36. Winterstein $A G$, Sauer $B C$, Hepler CD, Poole C. Preventable drug-related hospital admissions. Ann Pharmacother 2002;36:1238-48. [CrossRef] 